\title{
Mechanisms controlling the oxygen consumption in experimentally induced hypochloremic alkalosis in calves
}

\author{
Carole CAMBIER ${ }^{\mathrm{a}}$, Thierry ClerbauX ${ }^{\mathrm{b}}$, Hélène AMORYc ${ }^{\mathrm{c}}$, Bruno Detry ${ }^{\mathrm{b}}$, \\ Sandra FlorQuin ${ }^{\mathrm{a}}$, Vincent MARVILLE ${ }^{\mathrm{a}}$, Albert Frans ${ }^{\mathrm{b}}$, Pascal Gustina* \\ ${ }^{\text {a }}$ Department of Pharmacology and Toxicology, Faculty of Veterinary Medicine, \\ University of Liège, B-4000 Liège, Belgium \\ b Department of Internal Medicine, Division of Pneumology, Cliniques Universitaires Saint-Luc, \\ UCL, B-1200 Brussels, Belgium \\ ${ }^{c}$ Department of Large Animals Internal Medicine, Faculty of Veterinary Medicine, \\ University of Liège, B-4000 Liège, Belgium
}

(Received 17 September 2001; accepted 16 May 2002)

\begin{abstract}
The study was carried out on healthy Friesian calves $(n=10)$ aged between 10 and 30 days. Hypochloremia and alkalosis were induced by intravenous administration of furosemide and isotonic sodium bicarbonate. The venous and arterial blood samples were collected repeatedly. 2,3-diphosphoglycerate (2,3-DPG), hemoglobin and plasmatic chloride concentrations were determined. The red blood cell chloride concentration was also calculated. $\mathrm{pH}, \mathrm{PCO}_{2}$ and $\mathrm{PO}_{2}$ were measured in arterial and mixed venous blood. The oxygen equilibrium curve (OEC) was measured in standard conditions. The correspondence of the OEC to the arterial and mixed venous compartments was calculated, taking blood temperature, $\mathrm{pH}$ and $\mathrm{PCO}_{2}$ values into account. The oxygen exchange fraction $(\mathrm{OEF} \%)$, corresponding to the degree of blood desaturation between the arterial and mixed venous compartments and the amount of oxygen released at the tissue level by $100 \mathrm{~mL}$ of blood (OEF Vol\%) were calculated from the arterial and mixed venous $\mathrm{OEC}$, combined with $\mathrm{PO}_{2}$ and hemoglobin concentration. Oxygen delivery $\left(\mathrm{DO}_{2}\right)$ was calculated using the arterial oxygen content, the cardiac output measured by thermodilution, and the body weight of the animal. The oxygen consumption $\left(\mathrm{VO}_{2}\right)$ was derived from the cardiac output, OEF Vol\% and body weight values. Despite the plasma hypochloremia, the erythrocyte chloride concentration was not influenced by furosemide and sodium bicarbonate infusion. Due to the alkalosis-induced increase in the 2,3-DPG, the standard OEC was shifted to the right, allowing oxygen to dissociate from hemoglobin more rapidly. These changes opposed the increased affinity of hemoglobin for oxygen induced by alkalosis. Moreover, respiratory
\end{abstract}

*Correspondence and reprints

Tel.: (32) 436641 75; fax: (32) 436641 76; e-mail: p.gustin@ulg.ac.be 
acidosis, hemoconcentration, and the slight decrease in the partial oxygen pressure in mixed venous blood $\left(\mathrm{PvO}_{2}\right)$ tended to improve the OEF Vol\% and maintain the oxygen consumption in a physiological range while the cardiac output, and the oxygen delivery were significantly decreased. It may be concluded that, despite reduced oxygen delivery, oxygen consumption is maintained during experimentally induced hypochloremic alkalosis in healthy 10-30 day old calves.

\section{blood oxygen binding / oxygen equilibrium curve / oxygen consumption / hypochloremic alkalosis / calf}

Résumé - Mécanismes contrôlant la consommation en oxygène lors d'alcalose hypochlorémique induite expérimentalement chez le veau. Ces études ont été menées chez des veaux sains de type laitier, de race Frisonne ( $n=10)$, âgés de 10 à 30 jours. L'hypochlorémie et l'alcalose ont été induites par l'administration intraveineuse de furosémide et de bicarbonate de sodium isotonique. Des échantillons sanguins ont été prélevés, de manière répétée, au niveau artériel et veineux. Les concentrations en 2,3-diphosphoglycérate (2,3-DPG), en hémoglobine et en chlore plasmatique ont été déterminées. Les concentrations intra-érythrocytaires en chlore ont également été calculées. Les valeurs de $\mathrm{pH}$, $\mathrm{PCO}_{2}$ et $\mathrm{PO}_{2}$ ont été déterminées dans le sang artériel et veineux mêlé. La courbe de dissociation de l'oxyhémoglobine (OEC) a été tracée en conditions standards. Les courbes de dissociation de l'oxyhémoglobine correspondant aux compartiments artériel et veineux mêlé ont ensuite été calculées, tenant compte de la température sanguine ainsi que des valeurs de $\mathrm{pH}$ et $\mathrm{PCO}_{2}$. Le degré de désaturation du sang entre le compartiment artériel et le compartiment veineux mêlé (OEF \%) a été calculé, ainsi que la quantité d'oxygène libérée au niveau tissulaire, par $100 \mathrm{~mL}$ de sang (OEF Vol \%), considérant l'OEC artérielle et l'OEC veineuse et les valeurs de $\mathrm{PO}_{2}$ et de concentration en hémoglobine. L'apport en oxygène $\left(\mathrm{DO}_{2}\right)$ a été calculé en tenant compte du contenu artériel en oxygène, du débit cardiaque mesuré par thermodilution et du poids corporel de l'animal. La consommation d'oxygène $\left(\mathrm{VO}_{2}\right)$ a été calculée en fonction du débit cardiaque, de la quantité d'oxygène libérée au niveau tissulaire par $100 \mathrm{~mL}$ de sang et du poids corporel. Malgré l'hypochlorémie plasmatique, la concentration intra-érythrocytaire en chlore n'était pas influencée par l'administration de furosémide et de bicarbonate de sodium. Suite à l'augmentation du 2,3-DPG, induite par l'alcalose, la courbe de dissociation de l'oxyhémoglobine, mesurée en conditions standards était déviée vers la droite. Ces changements s'opposaient à l'augmentation de l'affinité de l'hémoglobine pour l'oxygène induite par l'alcalose. De plus, l'acidose respiratoire, l'hémoconcentration et la légère diminution de la pression partielle en oxygène au niveau veineux mêlé $\left(\mathrm{PvO}_{2}\right)$ tendaient à augmenter l'OEF $\mathrm{Vol} \%$ et à maintenir la consommation en oxygène à son niveau physiologique et ce malgré le fait que le débit cardiaque et l'apport en oxygène aient été diminués. Il peut donc être conclu que, malgré la diminution de l'apport en oxygène, la consommation d'oxygène est maintenue durant l'alcalose hypochlorémique induite expérimentalement chez le veau sain âgé de 10 à 30 jours.

transport de l'oxygène / courbe de dissociation de l'oxyhémoglobine / consommation en oxygène / alcalose hypochlorémique / veau

\section{INTRODUCTION}

Using hemoglobin solutions, Fronticelli et al. [15] first showed that bovine hemoglobin is more sensitive than human hemoglobin to the chloride-induced right shift of the oxygen equilibrium curve. The oxygen equilibrium curve (OEC) right shift induced by chloride in bovine hemoglobin was confirmed by Perutz et al. [25]. Be- cause hemoglobin functions differently in an artificial solution than in bovine red blood cells, in a previous study, Gustin et al. [20] recorded the whole blood OEC under standardized conditions with and without added chloride. They demonstrated that chloride induces a significant shift of the OEC to the right, likely by a direct action on hemoglobin. More recently, this effect was confirmed in vivo in healthy calves [4]. 
From these data, it can be hypothesized that the oxygen dissociation from hemoglobin may be compromised during hypochloremia. Hypochloremic metabolic alkalosis occurs in gastrointestinal diseases in cattle, especially abomasal displacement or volvulus, vagal indigestion, and stasis of the intestinal tract [23, 29]. In these cases, hypochloremia is often associated with alkalosis and other metabolic disorders like hypovolemia [11]. For example, inducing an experimental hypochloremic alkalosis by diversion of the abomasal outflow in sheep, Smith et al. [33] observed an increase in plasma L-lactate concentration, which probably reflected the development of hypovolemic shock and anaerobic metabolism associated with hypoperfusion. The present study was designed to assess the effects of hypochloremia and alkalosis on tissue oxygen consumption, oxygen delivery, and oxygen release to the tissues. A hypochloremic metabolic alkalosis was induced in healthy calves using furosemide and sodium bicarbonate. The parameters measured included the standard OEC, body temperature, acid-base balance, hemoglobin concentration, $\mathrm{PO}_{2}$ and $\mathrm{PCO}_{2}$ in arterial $\left(\mathrm{PaO}_{2}\right.$ and $\mathrm{PaCO}_{2}$, respectively) and mixed venous blood $\left(\mathrm{PvO}_{2}\right.$ and $\mathrm{PvCO}_{2}$, respectively), and cardiac output.

\section{MATERIALS AND METHODS}

\subsection{Experimental procedure}

The studies were carried out on healthy Friesian calves $(n=10)$ between 10 and 30 days of age, with body weights between 41 and $59 \mathrm{~kg}$. Using local anesthesia, a 14-gauge catheter (Vygon, France) and a $8.5 \mathrm{~F}$ catheter introducer (Baxter, Edwards, USA) were inserted percutaneously in the right and in the left jugular vein, respectively. A triple-lumen 7.5F Swan-Ganz catheter with a thermistor tip (Baxter, Edwards, USA) was inserted into the jugular vein through the introducer, and the distal tip of the catheter was advanced into the pulmonary artery. The position of the catheter was determined by identifying the characteristic pressure tracing derived from an extravascular pressure transducer (Baxter, Edwards, USA) and an amplifier monitor system (Marquette Hellige, Freiburg, Germany). After the placement of the catheters, the calves were left standing quietly for one hour to avoid the alterations induced by excitement.

Hypochloremia was induced by intravenous administration of $10 \mathrm{mg} / \mathrm{kg}$ of furosemide followed by continuous infusion of furosemide at a constant rate $(10 \mathrm{mg} / \mathrm{kg} / \mathrm{h})$ over three hours. At the same time, alkalosis was induced via a continuous intravenous infusion of isotonic sodium bicarbonate $\left(\mathrm{NaHCO}_{3} 1.4 \%\right)$ at a rate of $10 \mathrm{~mL} / \mathrm{kg} / \mathrm{h}$. The solutions were injected into the right jugular vein. At time 0 , defined as the start of infusion and at 30,60, 120 and 180 minutes, we used heparinized syringes to collect, under anaerobic conditions, $1 \mathrm{~mL}$ of mixed venous and $1 \mathrm{~mL}$ of arterial blood from the pulmonary and brachial arteries, respectively. The $\mathrm{pH}, \mathrm{PO}_{2}$ and $\mathrm{PCO}_{2}$, were measured immediately after sample procurement (AVL, Biomedical Instruments, Graz, Austria). The blood temperature obtained using the triple-lumen 7.5F Swan-Ganz catheter thermistor was used to correct the blood gas values and $\mathrm{pH}$. At each time point, venous blood samples were also collected from the jugular vein, using 20-mL heparinized syringes for aspiration of the samples. These samples were used for the determination of OEC and for blood analysis (see below). One milliliter of blood was frozen for determination of the erythrocyte chloride concentration. Plasma was also stored at $4{ }^{\circ} \mathrm{C}$ after $4 \mathrm{~mL}$ of venous blood were centrifuged for 15 minutes at $2600 \times g$ for determination of plasma chloride concentration. The remaining blood was immediately stored at $4{ }^{\circ} \mathrm{C}$, and the analyses were completed within 24 hours of sample collection. Previous 
studies conducted on bovine blood had shown that OEC was not modified if the analysis was realised within 24 hours after blood sampling. Indeed, the P50 standard values measured on 22 samples immediately after blood sampling and 24 hours later only differed from one another in $0.4 \%$. With sample collection, cardiac output was measured by thermodilution at each time point.

\subsection{Curve plotting}

The OEC was measured using a dynamic method under standard conditions (pH 7.4, $\mathrm{PCO}_{2} 40 \mathrm{~mm} \mathrm{Hg}$, temperature $37^{\circ} \mathrm{C}$ ) [7]. A $15-\mathrm{mL}$ venous blood sample was deoxygenated in a rotary tonometer with a gas mixture composed of $5.6 \% \mathrm{CO}_{2}$ $-94.4 \% \mathrm{~N}_{2}$. Blood was placed in a homemade analyzer and was equilibrated with this first gas mixture. Within 15 minutes, the oxygen tension was slowly increased from 0 to $320 \mathrm{~mm} \mathrm{Hg}$ by introducing a second gas mixture composed of $5.6 \% \mathrm{CO}_{2}-$ $94.4 \% \quad \mathrm{O}_{2}$. Oxygen saturation was measured by photometry (LED $660 \mathrm{~nm}$, Monsanto, St Louis, Mo) as a function of $\mathrm{PO}_{2} ; \mathrm{PO}_{2}$ was measured polarographically $\left(\mathrm{PO}_{2}\right.$ electrode, Eschweiler, Kiel, Germany). Changes in plasma $\mathrm{pH}$ were corrected automatically (to $\mathrm{pH} \mathrm{7.4)} \mathrm{by} \mathrm{addition}$ of $\mathrm{NaOH}(1 \mathrm{~N})$ or $\mathrm{HCl}(1 \mathrm{~N})$ in the analyzer. A temperature of $37{ }^{\circ} \mathrm{C}$ and a $\mathrm{PCO}_{2}$ of $40 \mathrm{~mm} \mathrm{Hg}$ were maintained throughout the determination of the OEC. For each curve, 100 points were automatically measured. The values for $\mathrm{PO}_{2}$ and oxygen saturation were stored on a computer for data processing and curve generation. The accuracy of our method for measuring OEC, expressed by the standard deviation of the $\mathrm{PO}_{2}$ at $50 \%$ hemoglobin saturation (P50), was $0.1 \mathrm{~mm}$ $\mathrm{Hg}$ for six curves determined for the same blood sample (analytic error of the analyzer), and $0.3 \mathrm{~mm} \mathrm{Hg}$ for 11 curves determined for 11 blood samples collected from the same control subject over a 30-day pe- riod (analytic error associated with intraindividual variations). The oxygen affinity changes were evaluated by measuring $\mathrm{PO}_{2}$ at $50 \%$ hemoglobin saturation under standard conditions (i.e., standard P50).

\subsection{Blood analysis}

The hemoglobin concentration, expressed in grams per $100 \mathrm{~mL}$ of blood, was determined with a hemoximeter (OSM3 Hemoximeter Radiometer, Copenhagen, Denmark). The hematocrit was measured by microcentrifugation (Universal $30 \mathrm{RF}$, Hettich, Tuttlingen, Germany). The 2,3-DPG concentration in blood was determined using an enzymatic method (DPG Kit $\mathrm{N}^{\mathrm{o}}$ 35A, Sigma Chemical Co, St Louis, MO, USA). The plasma chloride concentration was determined (Ciba Corning 288). The erythrocyte chloride concentration was determined according to the method described by Muylle et al. [24]. This technique was based upon the determination of whole blood ions ( $\mathrm{X}_{\mathrm{wB}}$ ) after hemolysis by deep freezing, plasma ions $\left(X_{P}\right)$, and hematocrit. The red blood cell ion concentrations were then calculated as follows: $100 /$ Hct $\left(X_{W B}-X_{P}\right)+X_{P}$. Total protein concentration in plasma was determined using the biuret method.

\subsection{Cardiac output determination}

The administration of drugs, i.e. furosemide and sodium bicarbonate was stopped during cardiac output determination, in order to avoid inaccurate readings. The cardiac output was measured by thermodilution after injecting $5 \mathrm{~mL}$ of cold $\left(0{ }^{\circ} \mathrm{C}\right) 5 \%$ dextrose solution through the proximal port of the triple-lumen $7.5 \mathrm{~F}$ Swan-Ganz catheter. Four successive measurements of the cardiac output were made and the results were averaged. After normalization for the body weight, the cardiac output was expressed in milliliters per minute per kilogram. 


\subsection{Oxygen exchange fraction (OEF) calculation}

The oxygen exchange fraction (OEF\%) is the degree of oxygen desaturation between arterial and mixed venous compartments, calculated using the arterial and mixed venous OEC, as well as the $\mathrm{PvO}_{2}$ and $\mathrm{PaO}_{2}$ values measured simultaneously. The arterial and venous OEC were calculated from the standard OEC corrected for the effects of $\mathrm{pH}$, temperature [8], and $\mathrm{PCO}_{2}$.

The amount of oxygen released to the tissue by $100 \mathrm{~mL}$ of blood (OEF Vol\%) was determined using the following formula:

$\mathrm{OEF}(\mathrm{Vol} \%)=\mathrm{Hb} \times \mathrm{BO}_{2} \times[\mathrm{OEF} \% / 100]$ $+\alpha\left(\mathrm{PaO}_{2}-\mathrm{PvO}_{2}\right)$

where $\mathrm{Hb}$ is the level of hemoglobin $(\mathrm{g} / 100 \mathrm{~mL}) ; \mathrm{BO}_{2}$ is the hemoglobin oxygen capacity $\left(1.39 \mathrm{~mL} \mathrm{O}_{2} / \mathrm{g} \mathrm{Hb}\right)[19]$; $\alpha$ is the oxygen solubility coefficient for blood at the temperature of the experiment $\left(0.003 \mathrm{~mL} \cdot 100 \mathrm{~mL}^{-1} \cdot \mathrm{mm} \mathrm{Hg}^{-1}\right) ; \mathrm{PaO}_{2}$ is the partial oxygen pressure in arterial blood, in $\mathrm{mm} \mathrm{Hg}$, and $\mathrm{PvO}_{2}$ is the partial oxygen pressure in mixed venous blood, in $\mathrm{mm} \mathrm{Hg}$.

\subsection{Systemic oxygen delivery calculation}

The systemic oxygen delivery $\left(\mathrm{DO}_{2}\right)$ was calculated as the product of the arterial blood oxygen content $\left(\mathrm{CaO}_{2}\right)$ and the cardiac output ( $\mathrm{CO}$ ) and was normalized to the body weight in kilograms. The arterial blood oxygen content and the systemic oxygen delivery were calculated as follows:

$$
\begin{aligned}
& \mathrm{CaO}_{2}\left(\mathrm{~mL} \mathrm{O}_{2} \cdot 100 \mathrm{~mL}^{-1}\right)= \\
& \mathrm{Hb} \times \mathrm{BO}_{2} \times\left[\mathrm{SaO}_{2} / 100\right]+\alpha\left(\mathrm{PaO}_{2}\right) . \\
& \mathrm{DO}_{2}\left(\mathrm{~mL} \mathrm{O}_{2} \cdot \mathrm{min}^{-1} \cdot \mathrm{kg}^{-1}\right)= \\
& \left(\mathrm{CO} \times \mathrm{CaO}_{2}\right) / \text { body weight. }
\end{aligned}
$$

\subsection{Oxygen consumption calculation}

Oxygen consumption $\left(\mathrm{VO}_{2}\right)$ was calculated as the difference between the arterial and mixed venous oxygen content (OEF $\mathrm{Vol} \%$ ) multiplied by the cardiac output (CO) and normalized to body weight in kilograms:

$\mathrm{VO}_{2}\left(\mathrm{~mL} \mathrm{O}_{2} \cdot \mathrm{min}^{-1} \cdot \mathrm{kg}^{-1}\right)=$ $[\mathrm{CO} \times \mathrm{OEF} \mathrm{Vol} \%] /$ body weight.

\subsection{Alveolar-arterial oxygen difference and physiologic shunt}

The alveolar-arterial oxygen gradient $\mathrm{P}(\mathrm{A}-\mathrm{a}) \mathrm{O}_{2}$ and physiologic shunt to total blood flow ratio $(\mathrm{Qs} / \mathrm{Qt})$ were calculated as classically described in the literature [10].

\subsection{Statistical analyses}

The values of the variables measured at each time were expressed as the means of individual values $\pm \mathrm{S}$.E. The values were tested for normal distribution by use of the Omnibus test. Data that were normally distributed were compared by the use of the paired Student t-tests or Aspin-Welch tests, depending on whether the variances were equal. When the data were not normally distributed, a non-parametric test was performed (Wilcoxon test). For all analyses, $P$ values of $<0.05$ were considered significant.

\section{RESULTS}

As illustrated in Figures 1 to 3, furosemide and sodium bicarbonate infusion induced significant alkalosis and plasma hypochloremia, which were maintained during the whole experiment. Even the red blood cell to plasma chloride ratio appeared to be constant, the erythrocyte chloride concentration did not decrease significantly during $120 \mathrm{~min}$ after starting infusion (see Tab. I). 
Table I. Influence of furosemide and bicarbonate infusion on the oxygen equilibrium curve, related indexes, $\mathrm{pH}$ and blood gases in calves

Time after starting infusion (min)

\begin{tabular}{|c|c|c|c|c|c|}
\hline & & & & & \\
\hline Parameters & Baseline & 30 & 60 & 120 & 180 \\
\hline P50 std, mm Hg & $22.2 \pm 0.6$ & $22.6 \pm 0.6$ & $22.7 \pm 0.7$ & $22.9 \pm 0.5^{*}$ & $23.0 \pm 0.6^{*}$ \\
\hline$\left[\mathrm{Cl}^{-}\right]_{\mathrm{RBC}}, \mathrm{mmol} / \mathrm{L}$ & $58.8 \pm 3.0$ & $55.5 \pm 3.3$ & $56.1 \pm 5.4$ & $54.1 \pm 4.1$ & $52.3 \pm 4.5^{*}$ \\
\hline$\left[\mathrm{Cl}^{-}\right]_{\mathrm{RBC}} /\left[\mathrm{Cl}^{-}\right]_{\mathrm{pl}}$ & $0.58 \pm 0.04$ & $0.56 \pm 0.05^{* *}$ & $0.59 \pm 0.06$ & $0.59 \pm 0.06$ & $0.59 \pm 0.06$ \\
\hline 2,3-DPG, $\mu \mathrm{mol} / \mathrm{g} \mathrm{Hb}$ & $10.3 \pm 1.0$ & $10.6 \pm 1.0^{*}$ & $10.7 \pm 1.0$ & $11.0 \pm 1.1 *$ & $10.9 \pm 1.0 *$ \\
\hline Temperature, ${ }^{\circ} \mathrm{C}$ & $38.8 \pm 0.1$ & $38.9 \pm 0.1$ & $38.9 \pm 0.1$ & $39.0 \pm 0.1$ & $39.0 \pm 0.1$ \\
\hline $\mathrm{PaCO}_{2}, \mathrm{~mm} \mathrm{Hg}$ & $46.6 \pm 0.9$ & $47.2 \pm 1.2$ & $46.8 \pm 1.4$ & $48.7 \pm 1.4^{*}$ & $50.7 \pm 0.9 * * *$ \\
\hline $\mathrm{PvCO}_{2}, \mathrm{~mm} \mathrm{Hg}$ & $55.2 \pm 1.6$ & $56.5 \pm 0.9$ & $58.7 \pm 1.3^{* *}$ & $60.7 \pm 1.5^{*}$ & $61.4 \pm 1.1^{* *}$ \\
\hline P50a, mm Hg & $25.2 \pm 0.7$ & $24.9 \pm 0.7$ & $24.9 \pm 0.9$ & $24.1 \pm 0.7 * *$ & $24.5 \pm 0.6^{*}$ \\
\hline $\mathrm{P} 50 \mathrm{v}, \mathrm{mm} \mathrm{Hg}$ & $27.8 \pm 0.7$ & $27.4 \pm 0.6$ & $27.7 \pm 0.9$ & $27.5 \pm 0.7$ & $27.1 \pm 0.7$ \\
\hline $\mathrm{PaO}_{2}, \mathrm{~mm} \mathrm{Hg}$ & $87.7 \pm 3.6$ & $82.1 \pm 3.9 *$ & $86.2 \pm 3.2$ & $83.8 \pm 5.0$ & $75.7 \pm 3.4 *$ \\
\hline $\mathrm{PvO}_{2}, \mathrm{~mm} \mathrm{Hg}$ & $34.7 \pm 1.7$ & $35.1 \pm 1.4$ & $33.1 \pm 1.2$ & $32.8 \pm 1.4$ & $32.6 \pm 1.8$ \\
\hline OEF $(\%)$ & $31.8 \pm 2.6$ & $29.2 \pm 2.7$ & $34.2 \pm 2.8$ & $34.0 \pm 3.2$ & $32.8 \pm 2.9$ \\
\hline $\mathrm{Hb}(\mathrm{g} / \mathrm{dL})$ & $9.5 \pm 0.4$ & $10.5 \pm 0.6^{* * * *}$ & $10.5 \pm 0.6 * * *$ & $10.6 \pm 0.6 * * *$ & $10.7 \pm 0.6 * * *$ \\
\hline OEF (Vol\%) & $4.2 \pm 0.3$ & $4.2 \pm 0.3$ & $4.9 \pm 0.4^{*}$ & $5.1 \pm 0.6$ & $4.9 \pm 0.5$ \\
\hline $\mathrm{CaO}_{2}\left(\mathrm{~mL} \mathrm{O}_{2} \cdot 100 \mathrm{~mL}^{-1}\right)$ & $13.0 \pm 0.6$ & $14.2 \pm 0.7^{* * *}$ & $14.2 \pm 0.7 * * *$ & $14.3 \pm 0.8 * * *$ & $14.3 \pm 0.8 * *$ \\
\hline $\mathrm{CO}\left(\mathrm{mL} \cdot \mathrm{min}^{-1} \cdot \mathrm{kg}^{-1}\right)$ & $142.0 \pm 10.7$ & $124.0 \pm 11.3^{*}$ & $109.0 \pm 12.2 * *$ & $109.0 \pm 13.0^{* * *}$ & $119.0 \pm 19.8 *$ \\
\hline $\mathrm{DO}_{2}\left(\mathrm{~mL} \mathrm{O}{ }_{2} \cdot \mathrm{min}^{-1} \cdot \mathrm{kg}^{-1}\right)$ & $18.5 \pm 1.8$ & $17.9 \pm 2.3$ & $15.7 \pm 2.2 *$ & $15.6 \pm 2.2^{*}$ & $17.3 \pm 3.3^{*}$ \\
\hline $\mathrm{VO}_{2}\left(\mathrm{~mL} \mathrm{O}{ }_{2} \cdot \mathrm{min}^{-1} \cdot \mathrm{kg}^{-1}\right)$ & $6.0 \pm 0.7$ & $5.1 \pm 0.5$ & $5.4 \pm 0.8$ & $5.4 \pm 0.8$ & $6.3 \pm 1.7$ \\
\hline Qs/Qt (\%) & $5.6 \pm 1.3$ & $7.9 \pm 1.5$ & $5.6 \pm 0.0$ & $6.2 \pm 1.2$ & $8.3 \pm 1.5^{*}$ \\
\hline $\mathrm{P}(\mathrm{A}-\mathrm{a}) \mathrm{O}_{2}(\mathrm{~mm} \mathrm{Hg})$ & $19.4 \pm 4.1$ & $24.4 \pm 3.5$ & $21.0 \pm 3.8$ & $22.7 \pm 2.3$ & $26.7 \pm 3.4$ \\
\hline
\end{tabular}

Values are expressed as means \pm SE. $n=10$, excepted for $\left[\mathrm{Cl}^{-}\right]_{\mathrm{RBC}}(n=5)$. P50std: $\mathrm{PO}_{2}$ at $50 \%$ hemoglobin saturation, measured in standard conditions $\left(\mathrm{pH} 7.4, \mathrm{PCO}_{2} 40 \mathrm{~mm} \mathrm{Hg}\right.$, temperature $\left.37^{\circ} \mathrm{C}\right) ;\left[\mathrm{Cl}^{-}\right]_{\mathrm{pl}}$ : plasmatic concentration of chloride, $\left[\mathrm{Cl}^{-}\right]{ }_{\mathrm{RBC}}$ : red blood cell chloride concentration, DPG: 2,3 diphosphoglycerate concentration, $\mathrm{pHa}, \mathrm{PaCO}_{2}, \mathrm{PaO}_{2}$ : $\mathrm{pH}$ and blood gases in arterial blood; $\mathrm{pHv}, \mathrm{PvCO}_{2}, \mathrm{PvO}_{2}: \mathrm{pH}$ and blood gases in mixed venous blood; OEF: oxygen exchange fraction; $\mathrm{Hb}$ : hemoglobin; $\mathrm{OEF} \mathrm{Vol} \%$ : amount of oxygen released at the tissue level by $100 \mathrm{~mL}$ of blood. $\mathrm{CaO}_{2}$ : arterial blood oxygen content; $\mathrm{CO}$ : cardiac output; $\mathrm{DO}_{2}$ : oxygen delivery; $\mathrm{VO}_{2}$ : oxygen consumption; Qs/Qt: physiologic shunt to total blood flow ratio; $\mathrm{P}(\mathrm{A}-\mathrm{a}) \mathrm{O}_{2}$ : alveolar-arterial oxygen gradient. *Value significantly different from value recorded at zero time $(* p<0.05 ; * *<<0.01 ; * * * p<0.001)$.

During hypochloremic alkalosis, standard P50 was significantly increased (23.0 $\pm 0.6 \mathrm{~mm} \mathrm{Hg} 180$ minutes after starting the infusion, versus $22.2 \pm 0.6 \mathrm{~mm} \mathrm{Hg}$ at the baseline, $p<0.05$ ), as well as the 2,3-DPG concentration $(10.9 \pm 1.0 \mu \mathrm{mol} / \mathrm{g}$ Hb versus $10.3 \pm 1.0 \mu \mathrm{mol} / \mathrm{g} \mathrm{Hb}$ at the same experi- mental time, $p<0.05)$. Body temperature was not significantly influenced by infusion and remained within the physiologic range. A progressive increase in $\mathrm{PvCO}_{2}$ was present, with hypercapnia observed after 60 minutes of bicarbonate/furosemide infusion. In the arterial blood, hypercapnia 


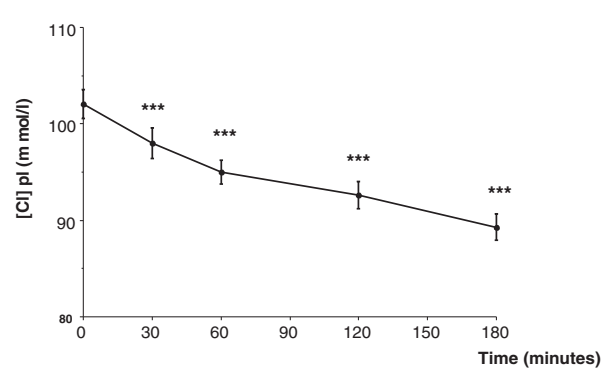

Figure 1. Effects of furosemide and bicarbonate infusion on plasma chloride $\left(\mathrm{Cl}^{-}\right)$concentration. Values are expressed as means \pm SE. *Value significantly different from the value recorded at zero time $(* * * p<0.001)$.

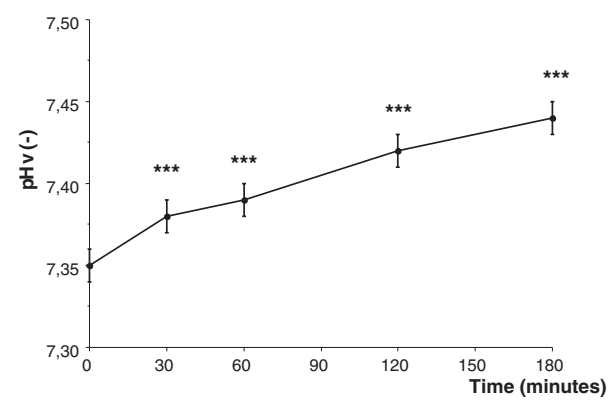

Figure 2. Effects of furosemide and bicarbonate infusion on $\mathrm{pH}$ in mixed venous blood $(\mathrm{pH}$ v). Values are expressed as means $\pm \mathrm{SE}$. *Value significantly different from the value recorded at zero time $(* * * p<0.001)$.

was observed 120 minutes after infusion. Compared to the baseline, the venous P50 did not change significantly during furosemide and sodium bicarbonate infusion. In the arterial blood, the hemoglobin oxygen affinity was only increased at the end of the experiment ( $t=120$ and 180 minutes), evidenced by a significant decrease in the P50 values $(24.5 \pm 0.6 \mathrm{~mm} \mathrm{Hg} 180$ minutes after starting infusion, versus $25.2 \pm 0.7 \mathrm{~mm} \mathrm{Hg}$ at the baseline, $p<0.05$ ).

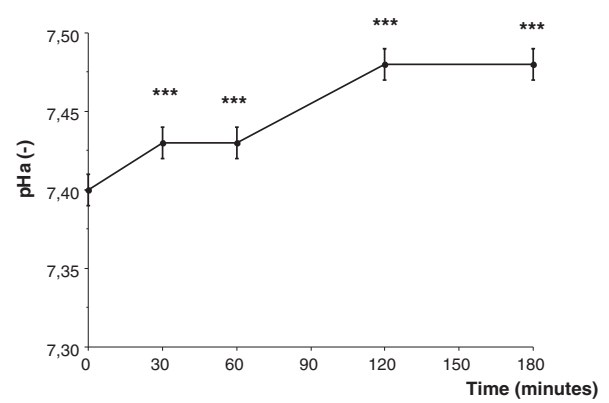

Figure 3. Effects of furosemide and bicarbonate infusion on $\mathrm{pH}$ in arterial blood $(\mathrm{pH}$ a). Values are expressed as means \pm SE. *Value significantly different from the value recorded at zero time $(* * * p<0.001)$.

Arterial hypoxemia was observed during hypochloremic alkalosis. Hypoxemia was especially marked at the end of the experiment $(75.7 \pm 3.4 \mathrm{~mm} \mathrm{Hg}$ versus $87.7 \pm$ $3.6 \mathrm{~mm} \mathrm{Hg}$ at zero time, $p<0.05)$. The partial pressure of oxygen in the mixed venous blood did not change significantly.

The oxygen exchange fraction $(\mathrm{OEF} \%)$ remained within the physiologic range during furosemide and bicarbonate administration. Due to the diurese-induced increase in the hemoglobin concentration, observed during the whole infusion time, the mean value of $\mathrm{OEF}$ Vol\% tended to increase (4.9 $\pm 0.4 \mathrm{~mL} \mathrm{O} \mathrm{O}_{2} / 100 \mathrm{~mL}$ of blood at time 60 minutes, versus $4.2 \pm 0.3 \mathrm{~mL} \mathrm{O}_{2} / 100 \mathrm{~mL}$ of blood before starting infusion, $p<0.05$ ). The cardiac output was significantly decreased in the presence of hypochloremic alkalosis ( $p<0.05$ at time 30 and $180 \mathrm{~min}$ utes; $p<0.01$ at time 60 and 120 minutes). Consequently, despite an increase in the arterial blood oxygen content, oxygen delivery stayed below the baseline value $(p<0.05)$ from 60 minutes after starting infusion to the end of the experiment. Systemic oxygen consumption did not change significantly during infusion, staying in its physiologic range. 
The physiologic shunt to total blood flow ratio was significantly increased $180 \mathrm{~min}$ utes after starting infusion $(p<0.05)$. The alveolar-arterial gradient also tended to increase, but not significantly.

\section{DISCUSSION}

The oxygen equilibrium curve (OEC) is the graphical representation of the degree of desaturation of hemoglobin with regards to the partial oxygen pressure. In all animal species, the factors identified as those which are able to modify the hemoglobin oxygen affinity are, notably the blood $\mathrm{pH}$, body temperature, partial carbon dioxide pressure, inorganic and organic phosphate as well as chloride ions. Acidosis, hyperthermia, hypercapnia, increase in organic and inorganic phosphate and hyperchloremia decrease the hemoglobin oxygen affinity, a factor in favour of tissular oxygenation. The relative influence of these regulating factors in humans is extensively described in the literature. In bovines, the relative importance of the factors regulating the oxyphoric function of the hemoglobin have also been identified [4-6, $20,21]$. Concerning the effects of chloride on bovine hemoglobin, it has been demonstrated in healthy calves infused with hypertonic saline solution, that the decrease in the hemoglobin oxygen affinity is not due to hypertonicity or changes in intracellular $\mathrm{pH}$ but to hyperchloremia itself [4]. However, the molecular mechanisms of chloride-induced intracellular changes leading to a shift in the oxygen equilibrium curve were not investigated in this study. Fronticelli et al. [15] demonstrated that bovine hemoglobin is more sensitive to this ion than human hemoglobin, in terms of the effect of chloride on P50. This higher sensitivity is attributed to the structural differences between both hemoglobins but also to the presence of specific chloride-binding sites in bovine hemoglobin. In ruminant $\beta$ chains, an arginine, which is located at the position of lysine in human hemoglobin, is a better ligand for chloride than lysine [16]. Although the OEC rightshift induced by chloride in bovine hemoglobin has been confirmed by Perutz et al. [26], the mechanism proposed to explain this effect is different from that suggested by Fronticelli [16]. They showed that chloride reduces the oxygen affinity of mammalian hemoglobin by acting as an allosteric effector, neutralizing the electrostatic repulsion in the cavity through the center of the molecule but without binding to any specific sites $[1,25,26]$. Increasing cardiac output, cardiac index, myocardial stroke work efficiency and improving ventilation-perfusion inequalities by a decrease in pulmonary arterial pressure and pulmonary vascular resistance, hypertonic saline solutions could also improve blood oxygen binding $[3,4]$. They are now used in bovine practices [34].

Taking into account the effects of chloride on oxyphoric function, it may be hypothesized that blood oxygen transport could be compromised with hypochloremia, a state which occurs commonly in cattle with proximal gastrointestinal obstruction [18]. Due to the sequestration of fluid, $\mathrm{H}^{+}$ and $\mathrm{Cl}^{-}$into the proximal gastrointestinal lumen, hypochloremia is usually accompanied by metabolic alkalosis and dehydration [23]. However, as in our experimental model, metabolic alkalosis and hypochloremia can also be associated to an increase in the strong ion difference.

Experimentally, hypochloremic metabolic alkalosis can be reproduced by sequestration or diversion of the abomasal content. This method has been used in sheep [35]. However, as it has been demonstrated in lactating cows, some animals do not tolerate the diversion process, becoming dehydrated and hypocalcemic, and deteriorating in clinical parameters [36]. In order to circumvent the animal's discomfort, a pharmacological model based on the administration of furosemide, a loop diuretic 
[13], and sodium bicarbonate has been described in the horse [14]. Using a similar pharmacological model in calves, we assessed the effects on tissue oxygen consumption, oxygen delivery, and oxygen release to the tissues of hypochloremia in combination with alkalosis.

All blood parameters recorded at time 0 (baseline values) were within their physiological range $[5,10,12]$, suggesting that all calves included in the study were without remarkable metabolic derangements or impairments in gas exchange. Experimentally-induced alterations in blood $\mathrm{pH}$ and plasma chloride concentrations approximate those seen in clinical disease. Poulsen et al. [27], studying a case of leftsided abomasal displacement changing to right-sided abomasal displacement observed a chloride plasmatic concentration of $97 \mathrm{mmol} / \mathrm{L}$ and $94 \mathrm{mmol} / \mathrm{L}$, respectively during left-sided and right-sided abomasal displacement. At the same time, the $\mathrm{pH}$ recorded in venous blood were 7.49 and 7.44 . According to Fubini et al. [17], 70\% of the cows with cecal volvulus are hypochloremic (plasmatic chloride concentration $\leq 90 \mathrm{mmol} / \mathrm{L}$ ) and have metabolic alkalosis. These results are in agreement with the modifications that we created using our experimental model; in practice, some more severe cases can sometimes be observed. For example, Habel et al. [22] reported a serum chloride concentration and a $\mathrm{pH}$ value of $71 \mathrm{mmol} / \mathrm{L}$ and 7.60 , respectively in a cow suffering from abomasal volvulus.

Although the plasma chloride concentration was decreased due to furosemide and sodium bicarbonate infusion, the hemoglobin oxygen affinity was not increased. On the contrary, oxygen affinity was decreased at the end of the experiment ( $t=120$ and $t=180$ minutes), evidenced by the increase in the P50 standard. This could be explained by the fact that even though furosemide and sodium bicarbonate infusion induced a plasma hypochloremia, the treatment failed to change the chloride concentrations in the erythrocyte. The red blood cells to plasma chloride ratio being constant, this phenomenon could be due to a greater variability in red blood cell chloride than in plasma chloride concentration. In humans and rats, it was previously shown that alkalosis increases the 2,3-DPG synthesis $[9,28]$ by phosphoglycerate mutase activation and phosphoglycerate phosphatase inhibition [2]. The same relation seems to exist in calves [3]. In healthy Friesian calves between 1 and 26 days of age, it has been demonstrated that the relationship between P50 std and 2,3-DPG was: P50 std $(\mathrm{mm} \mathrm{Hg})=20.06+0.14$ [2,3-DPG], where P50 std is the partial oxygen pressure corresponding to $50 \%$ saturation of hemoglobin, measured in standard conditions, and [2,3-DPG] is the 2,3-DPG concentration in the blood, expressed in $\mu \mathrm{mol} / \mathrm{g} \mathrm{Hb}$ [5]. However, in cattle, the level of 2,3-DPG is very low $(<1 \mu \mathrm{mol} / \mathrm{g} \mathrm{Hb})$.

The changes recorded in the standard P50 are insufficient to enable us to assess the influence of an experimentally induced pathological process on in vivo blood oxygen binding, since factors such as $\mathrm{pH}$, body temperature and $\mathrm{PCO}_{2}$ shift the OEC and influence related parameters such as $\mathrm{OEF} \%$ and $\mathrm{OEF}$ Vol\%. Metabolic alkalosis increases the affinity of hemoglobin for oxygen in all species, including cattle, by shifting the OEC to the left. The alkalosis-induced shift of the OEC can be considered as a factor limiting tissue oxygenation. Alkalosis also causes the 2,3-DPG level to increase, which counteracts the Bohr effect on blood oxygen transport. In adult cattle, it can be suspected that this mechanism does not exist, due to the very low synthesis of 2,3-DPG. Moreover, during experimentally induced hypochloremic alkalosis, the OEC right shift induced by compensatory respiratory acidosis [30] also counteracts the effects of alkalosis on blood oxygen transport. The influence of temperature in the bovine OEC has been previously described [5]. However, in the present study, a lack of 
difference in body temperature eliminated this factor as having an influence on the oxygen equilibrium curve.

Due to the combined effects of all these factors, the in vivo P50 values did not significantly change during the experimentally induced hypochloremic alkalosis, except in the arterial compartment at the end of the experiment. Indeed, two and three hours after starting infusion, the arterial P50 was significantly decreased.

Oxygen release at the tissue level is not only determined by the position of the OEC but also by the partial pressure of oxygen in arterial and venous blood. We observed a fall in the partial oxygen pressure in arterial blood during experimentally induced hypochloremic alkalosis. This observation was in agreement with the results of Ward et al., who created a model of diversion of the abomasal content in sheep [35]. Arterial hypoxemia can originate from hypoventilation, diffusion impairment, ventilation-perfusion inequality or a shunt [10]. In this study, arterial hypoxemia observed at the end of the experiment seemed to result from the shunt. Arterial hypoxemia could induce a drop in the OEF values. However, the influence of hypoxemia was limited, because at this point on the OEC, a difference in $\mathrm{PaO}_{2}$ of $10 \mathrm{~mm} \mathrm{Hg}$ causes only a $1 \%$ difference in hemoglobin saturation. In mixed venous blood, the partial pressure of oxygen was also slightly decreased. Even though non-significant, this fact contributed to increase the extraction of oxygen at the tissue level, the plateau of OEC not being reached.

Due to the combined influence of all these factors, the OEF values did not change significantly during experimental hypochloremic alkalosis. However, diuresis induced by furosemide infusion resulted in a decreased plasma volume, as indicated by the increase in the hemoglobin concentration and plasma protein concentration $(71.8 \pm 3.1 \mathrm{~g} / \mathrm{L}$, 3 hours after starting infusion, versus $64.3 \pm$
$2.7 \mathrm{~g} / \mathrm{L}$ at zero time). In naturally occurring gastro-intestinal obstruction, diseaserelated factors such as endotoxemia and shock could reinforce hypovolemia and hemoconcentration $[23,27]$. Due to the effects of hemoconcentration, the amount of oxygen released at the tissue level by $100 \mathrm{~mL}$ of blood was increased. Consequently, despite a drop in oxygen delivery at the tissue level, due to the fall in the cardiac output also attributed to the hemoconcentration, oxygen consumption did not decrease significantly during experimentally induced hypochloremic alkalosis. This phenomenon has been previously described in the literature. Indeed, over a wide range of cardiac output, $\mathrm{VO}_{2}$ is independent of $\mathrm{DO}_{2}$, since the tissues are able to increase the extraction of oxygen from the blood $[31,32]$. This independence between $\mathrm{DO}_{2}$ and $\mathrm{VO}_{2}$ reflects the compensatory properties of the blood oxygen transport system. However, this compensatory mechanism requires adequate blood flow. Indeed, when blood flow maldistribution occurs, as during bacteriemia or endotoxic shock $[6,10], \mathrm{VO}_{2}$ becomes dependent on $\mathrm{DO}_{2}$. This did not seem to be the case during the present experiment. However, it must be noted that some cattle with a right displacement of the abomasum or severe proximal enteritis may be endotoxemic.

It can be concluded that during pharmacologically induced hypochloremic alkalosis, the oxygen consumption was maintained within physiological ranges, despite decreased oxygen delivery, in healthy 10 30 day old calves. More efficient oxygen extraction at the tissue level was attributed to a reduced affinity of oxygen for hemoglobin, secondary to the increase in the 2,3-DPG concentration and compensatory respiratory acidosis as well as hemoconcentration.

\section{ACKNOWLEDGEMENTS}

This work was supported by the DGTRE (Walloon Region-Grants no 3012, 2555, 981/3676 and 981/3677). 


\section{REFERENCES}

[1] Bonaventura C., Arumugan R., Cashon R., Bonaventura J., Moo-Penn W.F., Chloride masks effects of opposing positive charges in $\mathrm{HbA}$ and $\mathrm{Hb}$ Hinsdale (b 139 Asn $\rightarrow$ Lys) that can modulate cooperativity as well as oxygen affinity, J. Mol. Biol. 239 (1994) 561-568.

[2] Bossi D., Giardina B., Red cell physiology, Mol. Aspects Med. 17 (1996) 117-128.

[3] Cambier C., Ratz V., Rollin F., Frans A., Clerbaux t., Gustin P., The effects of hypertonic saline in healthy and diseased animals, Vet. Res. Commun. 85 (1997) 303-316.

[4] Cambier C., Detry B., Beerens D., Florquin S., Ansay M., Frans A., Clerbaux T., Gustin P., Effects of hyperchloremia on blood oxygen binding in healthy calves, J. Appl. Physiol. 85 (1998) $1267-1272$

[5] Cambier C., Clerbaux T., Detry B., Beerens D., Frans A., Gustin P., Blood oxygen binding in double-muscled calves and dairy calves with conventional muscle conformation, Am. J. Vet. Res. 61 (2000) 299-304.

[6] Cambier C., Clerbaux T., Moreaux B., Detry B., Beerens D., Frans A., Gustin P., Blood oxygen binding in calves with naturally occurring diarrhea, Am. J. Vet. Res. 62 (2001) 799-804.

[7] Clerbaux Th., Fesler R., Bourgeois J., A dynamic method for continuous recording of the whole blood oxyhemoglobin dissociation curve at constant temperature, $\mathrm{pH}$ and $\mathrm{PCO}_{2}, \mathrm{Med}$. Lab. Technol. 30 (1973) 1-9.

[8] Clerbaux T., Gustin P., Detry B., Cao M.L., Frans A., Comparative study of the oxyhaemoglobin dissociation curve of four mammals: man, dogs, horse and cattle, Biochem. Physiol. 106A (1993) 687-694

[9] Clerbaux Th., Detry B., Reynaert M., Frans A., Right shift of the oxyhemoglobin dissociation curve in acute respiratory distress syndrome, Pathol. Biol. 45 (1997) 269-273.

[10] Constable P.D., Schmall M., Muir W.W., Hoffsis G.F., Respiratory, renal, hematologic, and serum biochemical effects of hypertonic saline solution in endotoxemic calves, Am. J. Vet. Res. 52 (1991) 990-998.

[11] Dirksen G.U., Tympany, displacement and torsion of the abomasum in calves: pathogenesis, diagnosis and treatment, The bovine Practitioner 28 (1994) 120-126.

[12] Dupe R., Bywater R.J., Goddard M., A hypertonic infusion in the treatment of experimental shock in calves and clinical shock in dogs and cats, Vet. Rec. 133 (1993) 585-590

[13] English P.B., Becvar W.E., Effects of furosemide on the external balances of water, sodium, potassium and chloride in sheep, Am. J. Vet. Res. 32 (1971) 1371-1379.
[14] Freestone J.F., Carlson G.P., Harrold D.R., Church G., Furosemide and sodium bicarbonate-induced alkalosis in the horse and response to oral $\mathrm{KCl}$ or $\mathrm{NaCl}$ therapy, Am. J. Vet. Res. 50 (1989) 1334-1338.

[15] Fronticelli C., Bucci E., Orth C., Solvent regulation of oxygen affinity in hemoglobin, J. Biol. Chem. 259 (1984) 10841-10844.

[16] Fronticelli C, A possible new mechanism of oxygen affinity modulation in mammalian hemoglobins, Biophys. Chem. 37 (1990) 141-146.

[17] Fubini S.L., Hollis N.E., Rebhun W.C., Horne D., Cecal dilatation and volvulus in dairy cows: 84 cases (1977-1983), J. Am. Vet. Med. Assoc. 189 (1986) 96-99.

[18] Fubini S.L., Smith D.F., Grohn Y.T., Levine S.A., Deuel D.M., Replacement of chloride deficit by use of $1.8 \% \mathrm{NaCl}$ to correct experimentally induced hypochloremic metabolic alkalosis in sheep, Am. J. Vet Res. 52 (1991) 1898-1902.

[19] Gustin P., Clerbaux T., Willems E., Lekeux P., Lombe F., Frans A., Oxygen transport properties in blood in two different bovine breeds, Comp. Biochem. Physiol. A 89 (1988) 553-558.

[20] Gustin P., Detry B., Cao M.L., Chenut F., Robert A., Ansay M., Frans A., Clerbaux T., Chloride and inorganic phosphate modulate binding of oxygen to bovine red blood cells, J. Appl. Physiol. 77 (1994) 202-208.

[21] Gustin P., Detry B., Robert A., Cao M.L., Lessire F., Cambier C., Katz V., Ansay M., Frans A., Clerbaux T., Influence of age and breed on the binding of oxygen to red blood cells of bovine calves, J. Appl. Physiol. 82 (1997) 784-790.

[22] Habel R.E., Smith D.F., Volvulus of the bovine abomasum, J. Am. Vet. Med. Assoc. 179 (1981) 447-455.

[23] Howard J.L., Diseases of the digestive system., in: Howard J.L. (Ed.), Current Veterinary Therapy, Food Animal Practice, Third Edition, Saunders Company, Philadelphia, 1993, pp. 706761.

[24] Muylle E., Van Den Hende C., Nuytten J., Deprez P., Vlaminck K., Oyaert W., Potassium concentration in equine red blood cells: normal values and correlation with potassium levels in plasma, Equine Vet. J. 16 (1984) 447-449.

[25] Perutz M.F., Fermi G., Poyart C., Pagnier J., Kister J., A novel allosteric mechanism in haemoglobin, J. Mol. Biol. 233 (1993) 536-545.

[26] Perutz M.F., Shih D.T.B., Williamson D., The chloride effect in human hemoglobin. A new kind of allosteric mechanism, J. Mol. Biol. 239 (1994) 555-560.

[27] Poulsen J.S.D., Clinical chemical examination of a case of left-sided abomasal displacement, changing to right-sided abomasal displacement, Nord. Vet. Med. 26 (1974) 91-96. 
[28] Przybylski J., Skotnicka-Federowicz B., Lisiecka A., Sinski M., Abramczyk P., The increased concentration of 2,3 diphosphoglycerate in red blood cells of spontaneously hypertensive rats, J. Physiol. Pharmacol. 48 (1997) 873-881.

[29] Roussel A.J., Cohen N.D., Holland P.S., Taliaoferro L., Green R., Benson P., Navarre C.B., Hooper R.N., Alterations in acid-base balance and serum electrolyte concentrations in cattle: 632 cases (1984-1994), J. Am. Vet. Med. Assoc. 212 (1998) 1769-1775.

[30] Ruckebusch Y., Phaneuf L.P., Dunlop R., Respiratory regulation of acid-base balance, in: Decker (Ed.), Physiology of small and large animals, Philadelphia, 1991, pp. 92-97.

[31] Samsel R.W., Nelson D.P., Sanders W.M., Wood L.D.H., Schumacker P.T., Effect of endotoxin on systemic and skeletal muscle $\mathrm{O}_{2}$ extraction, J. Appl. Physiol. 65 (1988) 1377-1382.

[32] Schlichtig R., kramer D.J., Pinsky M.R., Flow redistribution during progressive hemorrhage is a determinant of critical delivery, J. Appl. Physiol. 70 (1991) 169-178.
[33] Smith D.F., Lunn D.P., Robinson G.M., McGuirk S.M., Nordheim E.V., MacWilliams P.S., Experimental model of hypochloremic metabolic alkalosis caused by diversion of abomasal outflow in sheep, Am. J. Vet. Res. 51 (1990) 1715-1720.

[34] Suzuki K., Ajito T., Iwabuchi S., Effect of infusion of hypertonic saline solution on conscious heifers with hypoxemia caused by endotoxin infusion, Am. J. Vet. Res. 59 (1998) 452-457.

[35] Ward J.L., Smith D.F., Fubini S.L., Gröhn Y.T., Comparison of $0.9,3.6$ and $7.2 \mathrm{NaCl}$ for correction of experimentally induced hypochloremic, hypokalemic metabolic alkalosis in sheep, Am. J. Vet. Res. 54 (1993) 1160-1169.

[36] Ward J.L., Smith D.F., Fubini S.L., Deuel-Aromando D.M., Evaluation of abomasal diversion as an experimental model of hypochloremic, hypokalemic metabolic alkalosis in lactating cows, Can. J. Vet. Res. 58 (1994) 13-19. 